\title{
Running Out of Time: The Demographics of Saving
}

When it comes to consumption and saving, there are two groups of people: those who produce resources actively in the labor market, and those who depend on what others produce because they are either too young or too old to work. For the world as a whole, the ratio of potential dependents to producers has been declining since 1965-mostly because fertility rates have dropped more quickly than life expectancy has increased. However, this shift in the age structure of society-the socalled demographic dividend-is ending (Figure 6.1.) ${ }^{1}$

The steady decline of the dependency ratio worldwide since 1965 stopped in 2010 (United Nations, 2015). From now on, the gains of having fewer young people to care for will be outweighed by the burden of having to attend to a growing elderly population. ${ }^{2}$

Nowhere in the world will these demographic changes be as intense as in Latin America and the Caribbean. For the past five decades, the region's decline in the dependency ratio has been the steepest in the world. In 1965, for each 100 individuals of working age (15 to 65 years old) in the region, there were 90 young and old dependents; today there are fewer than 50 . In a way, this has been a gift. A greater number of people have been contributing to production, savings, and growth. However, the gift is really a loan that will have to be repaid in the decades to come. As the low fertility rates that triggered the demographic dividend play out, countries will age, and they will age rapidly. The demographic dividend is projected to end in 2020 . From 2020 to 2100 , the number of dependents will increase by 35.5-again the largest increase of any region (Figure 6.1). In 2085, Latin America and the Caribbean will surpass Europe as the region with the highest share of elderly per working age population (ECLAC, 2014b).

Providing for the elderly is an enormous task that the region is not ready to undertake. Aging will put more pressure on already scarce 
Figure 6.1 Extension of the Demographic Dividend

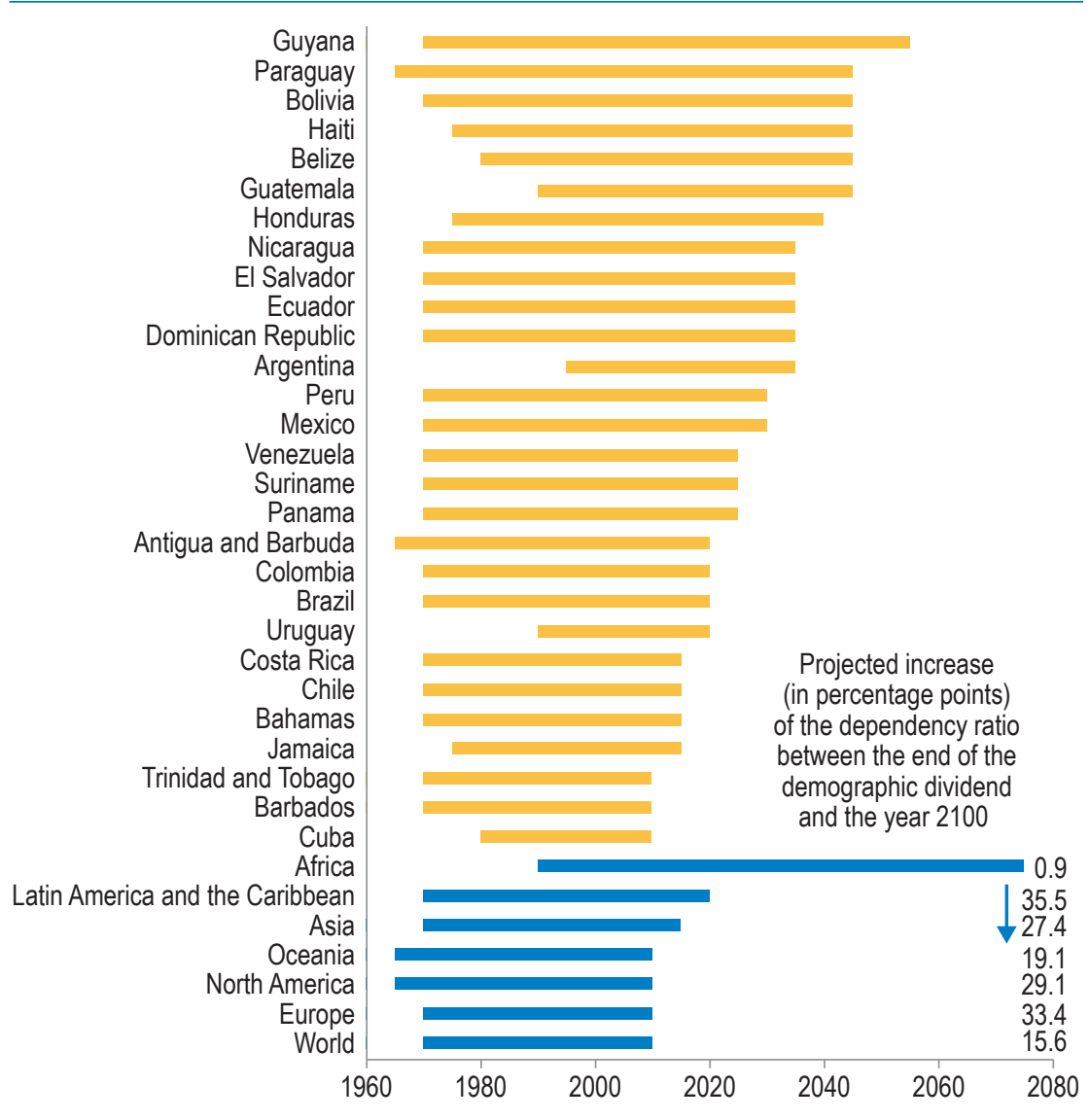

Source: Authors' calculations based on United Nations (2015).

Note: The bars depict the period in which the total dependency ratio (Population $<15$ + Population $>65$ /Population 15-64) is falling.

funds to finance development. The future of an aging society is a challenge that requires action sooner rather than later. However, conveying the need for swift action to policymakers is difficult because the region is still enjoying the demographic dividend. Demographic trends fueled an important part of the region's recent economic performance. ${ }^{3}$

Not all the news is bad. Demographics will still provide room for maneuver for several years-in some countries more than in others. For countries like Belize, Bolivia, Guatemala, Guyana, Haiti, and Paraguay, the demographic dividend will last two to three more decades (Figure 6.1). For countries like Bahamas, Barbados, Chile, Costa Rica, Cuba, Jamaica, and Trinidad and Tobago, the demographic dividend is all but gone. 
Figure 6.2 Age Profile in Latin America and the Caribbean

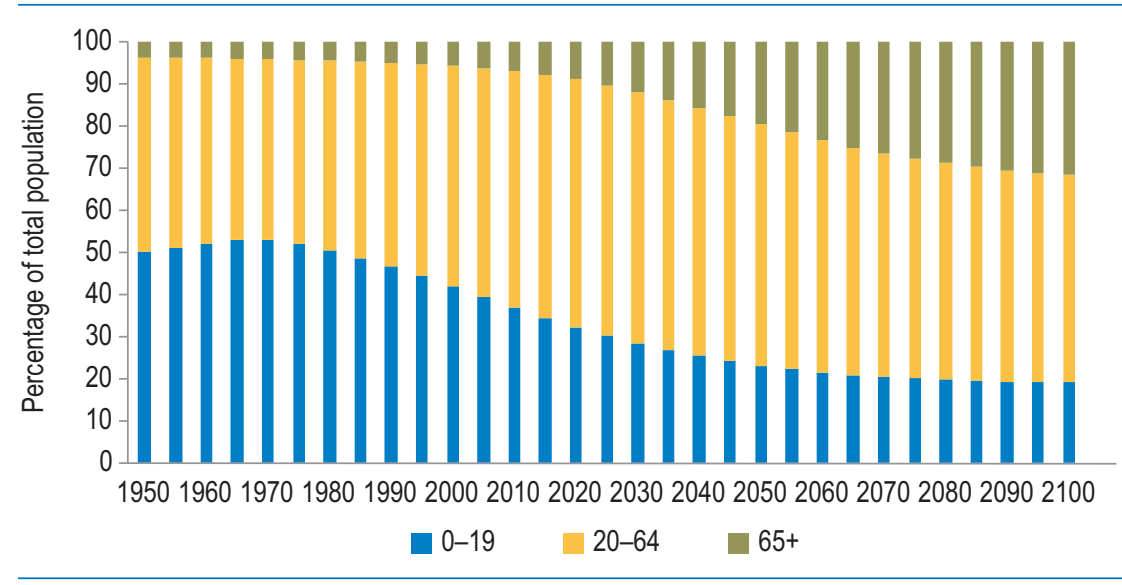

Source: Authors' calculations based on United Nations (2015).

However, even for these countries, the dependency ratios, while increasing, will remain relatively low by historical standards for several years (United Nations, 2015). In addition, the region has other unexploited dividends that can extend the demographic dividend, at least temporarily. One of them is the increase in the participation of women in labor market. Female participation rates are still low, compared to more advanced countries (Morton et al., 2014). Another is to decrease the large share of youngsters who are neither participating in the labor market nor studying. Some 22 percent of the region's youth were idle in 2013 (Alaimo et al., 2015). Furthermore, reducing the large share of the labor force who do not work in the formal sector-and thus do not pay taxes or contribute to pensions-could help to boost savings and growth (Bosch, Melguizo, and Pagés, 2013; Levy, 2008; Hsieh and Klenow, 2014).

Governments, households, and firms must address the challenge of population aging by combining efforts. This chapter argues that improving savings in general and pension systems in particular, are necessary steps to ensure that longer lives will mean better lives.

\section{More Elderly with More Needs}

During the past 40 years, the age profile of the population and dependency ratios in Latin America and the Caribbean have changed dramatically. Figure 6.2 shows how this profile has evolved and how it is likely to continue. The change in the share of the population over 65 years 
old is especially striking, from a very small portion 50 years ago to a significant percentage in the future. At the same time, fertility has fallen from 5.9 births per 1,000 women in 1950-55 to 2.15 in 2010-15, and is projected to decline even further to 1.78 in 2045-50. Around 2050, life expectancy and fertility rates in Latin America and the Caribbean are expected to converge to the levels of more advanced countries (United Nations, 2015).

Not only will the number of older people be greater, but so too will the portion of the very old with higher needs. While less than 2 percent of the population in Latin America and the Caribbean is older than 85 , by the end of the century, that share will increase to more than 8 percent. The need for care of the elderly over the age of 85 increases significantly, despite technological advances. The share of adults that need help with functional activities of daily life (FADL) or instrumental activities of daily life (IADL) ${ }^{4}$ increases between two to five times after the age of 80, surveys conducted in Latin American cities in 2002 indicate (Table 6.1). Other sources suggest the same pattern. For instance, a survey conducted in Chile in 2009 showed that 12.8 percent of the elderly aged 60-64 were dependent in some way, while this percentage increased to more than 65 percent at ages 85 or over (SENAMA, 2009). This situation is similar in more advanced countries with better health systems. In countries like Italy, Germany, and Spain, the increase in the case of FADL is from nearly 10 percent at ages 60-64 to more than 30 percent for those over 75 years old. In the case of IADL, dependence at older ages is three times higher than for those between 65 and

\section{Table 6.1 Elderly with Limitations Who Receive Help with Daily Activities} (Percentage)

\begin{tabular}{lccccccc}
\hline & $\begin{array}{c}\text { Buenos } \\
\text { Aires, } \\
\text { Argentina }\end{array}$ & $\begin{array}{c}\text { Bridgetown, São Paulo, } \\
\text { Barbados }\end{array}$ & $\begin{array}{c}\text { Santiago, } \\
\text { Brazil }\end{array}$ & $\begin{array}{c}\text { Havana, } \\
\text { Cuba }\end{array}$ & $\begin{array}{c}\text { Mexico } \\
\text { City, } \\
\text { Mexico }\end{array}$ & $\begin{array}{c}\text { Montevideo, } \\
\text { Uruguay }\end{array}$ \\
\hline FADL & & & & & & & \\
$65-80$ & 4.0 & 4.6 & 7.7 & 10.2 & 6.7 & 6.4 & 3.8 \\
$80+$ & 18.8 & 17.8 & 21.9 & 33.8 & 23.2 & 24.4 & 13.8 \\
IADL & 11.2 & 14.7 & 31.1 & 23.1 & 20.7 & 25.3 & 9.9 \\
$65-80$ & 29.1 & 36.8 & 59.6 & 55.1 & 50.7 & 51.8 & 35.4 \\
\hline $80+$ & & & & & & & \\
\hline
\end{tabular}

Source: Authors' calculations based on the Health, Well-being and Aging Survey (CDE and others, 2002).

Note: FADL = functional activities of daily living; IADL = instrumental activities of daily living. 
74, reaching almost 40 percent in countries like Italy and Spain. Therefore, even if overall health conditions in Latin America and the Caribbean improve, dependency rates of the very elderly will still likely increase as life expectancy rises. Compounding the problem, as societies age, more people need care, but fewer caregivers are available, given the drop in fertility (WHO, 2015).

In a world where more people are both elderly and dependent, two main challenges loom for future generations: providing health care and income support (pensions) for the elderly. Combined, these challenges could prove burdensome.

Taking care of the elderly is substantially more expensive than taking care of the young. Evidence from both OECD member-states and Latin American and Caribbean countries shows that people spend a substantial portion of their medical expenses in the last decade of life, and that the percentage of people at this stage is increasing as the population ages. Health care spending in per capita terms is between four and ten times higher for an 80 year-old than for a 3 year-old (see Figure 6.3).

The shift in population composition will substantially increase health care costs. Currently, the elderly consume 17 percent of total health expenditures in Latin America and the Caribbean (even though they make up less than 8 percent of the population): this share is projected to rise to over

\section{Figure 6.3 Public and Private Consumption of Health Care over a Lifetime}

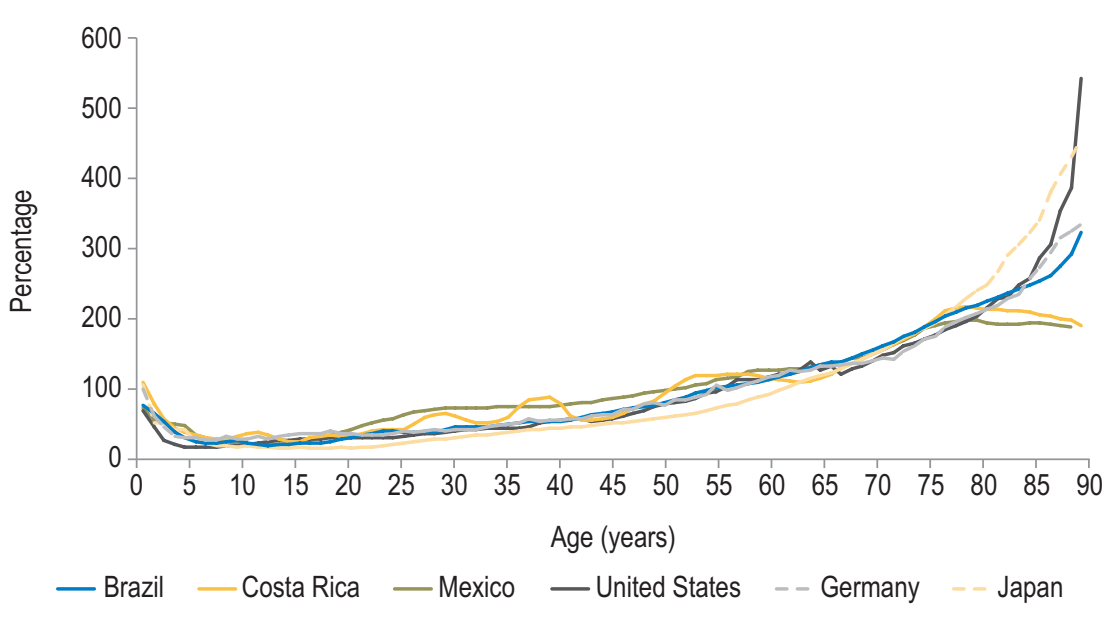

Source: Authors' calculations based on National Transfer Accounts Database, http://www.ntaccounts.org.

Note: Per capita health care consumption as a percentage of lifetime average health care consumption. 
50 percent in 2070 (United Nations, 2015). Today, families finance much of the health care needs of the elderly, but as the size of families shrinks, it will be harder to cope with higher costs. Thus, countries will have to find resources to finance curative and palliative services. Preventive services are another way to control costs and improve the health of the elderly. The role of chronic diseases on the costs of health care, and the prevalence of these conditions at old age, have been well documented. Future health expenditures due to the change in the age structure will depend on actions taken to prevent the impact of chronic disease (see Saad, 2011).

The other major challenge for Latin America and the Caribbean will be how to finance pensions, particularly because, despite relatively young populations, governments are already spending substantially more on the old than on the young. Indeed, total spending on education in Brazil and Uruguay accounted for 5.3 percent and 3.8 percent of GDP in 2009, respectively, and total spending on social security and pensions reached 13.8 percent and 11.7 percent on the same year for these 2 countries. In per capita terms, current public benefits for the young are significantly lower than for the elderly. For instance, on average for the region, public expenditure on social security and pensions per person older than 65, amounted to more than five times the level of expenditure on education per child under 20 in 2015 (ECLAC, 2015a).

Population aging will increase the pensions' financing challenge as well. One way to quantify the magnitude of this challenge is to calculate what would be the future level of spending on pensions taking into account the projected demographic changes. If by 2100 the region keeps spending the same amount per person over 65 (as a share of GDP) on pensions as it is spending now, total expenditure would have to increase five-fold on average. Some countries, including Argentina, Bolivia, Brazil, Panama, and Venezuela, might need to spend more than 20 percent of GDP on pensions (Figure 6.4). This amount of spending on pensions alone would probably crowd out other expenditures. If nothing is done, then the region might end up spending less on other productivity-enhancing investments just when boosting productivity would be critical for growth in the region in the face of aging.

Countries need to understand that more resources will inevitably be required to address the necessities of an aging population. How much will be needed in the future depends greatly on the package of benefits promised to the elderly, and on when they would start receiving those transfers. More developed countries, which are at a further advanced 
Figure 6.4 Current and Future Public Spending on Pensions

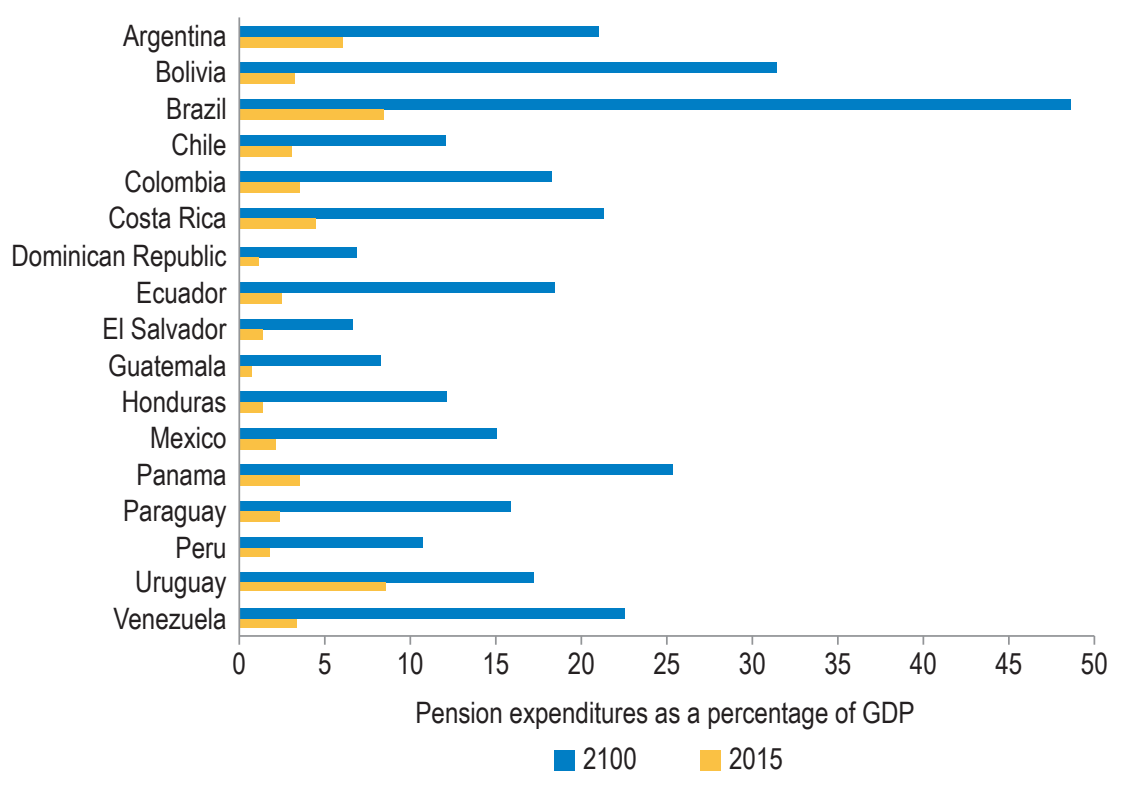

Source: Authors' calculations based on ECLAC (2015b) and CELADE (2015).

Note: Pension spending in 2015 is calculated by multiplying the average pension by the share of pension recipients according to household surveys (see Chapter 7 for details). Pension expenditures in 2100 are calculated leaving expenditure per capita (as a share of GDP) constant at 2015 levels multiplied by the growth factor of people over 65 between 2015 and 2100.

stage in the demographic transition, should be a reference for the region to prepare adequately for the challenge that aging presents. Providing adequate conditions for the elderly to decide how long to work is an important component of old-age policies. Pensions are a critical element in this equation (Chapter 7 ).

\section{Facing the Challenge: More and Better Savings}

To meet the needs of the elderly, countries can pursue essentially two strategies. One is to "promise" the elderly that societies will take care of them (in exchange for contributions made during the working years, as part of family arrangements, or as a citizen's right). The other is to set resources aside (i.e., saving) when countries are young and use them as they age. ${ }^{5}$ Pension arrangements broadly follow these two strategies (see Box 6.1). It is important to understand that aging will pose important challenges to both strategies. 


\section{Fulfilling Promises}

Promising a pension in the future in exchange for contributions today is how most pension systems in the world operate. Most mandatory pension systems have at least a component that is a defined-benefit system (PAYG/DB), either unfunded or usually only partially funded. In these systems, the contributions of current workers' pay for the pensions that were promised in the past to other workers (see Box 6.1).

Fulfilling that promise in periods of rapid demographic change is a challenge. As the proportion of the elderly increases, more and more resources are required from the shrinking pool of working populations in the form of pension contributions, taxes, or intra-family transfers. The kind of promises a country can afford is largely driven by demographic trends (see Box 6.2). As these trends change, so do the implicit rates of return that a pay-as-you-go (PAYG/DB) system can offer in a sustainable way, given a certain level of contributions and a certain retirement age.

\section{BOX 6.1. PENSION SYSTEMS: DEFINING THE CONCEPTS}

\section{Types of pension systems}

Defined-benefit systems (DB). The pension level is determined by a rule based on the number of contributions and the employee's salary in the final years of work. The benefits rule may be set according to the final salary payment or a longer period (such as the final five or ten years of contributions). This rule is usually not actuarially fair, and entails subsidies within or across generations. This type of system can be funded or not; it is usually partially funded.

Defined-contribution system (DC). The pension is determined by the value of the assets accumulated by an individual over his or her working life. The benefits may be withdrawn all at once, scheduled for programmed withdrawals, or used to purchase an annuity, which would provide monthly income for the remainder of the individual's life. The formula is actuarially fair. There are no subsidies across or within generations, unless there is a guaranteed minimum pension. Usually these systems are funded, but not necessarily. When the system is not funded, it is called a notional defined contribution system.

Noncontributory pension (NCP) or Social Pensions (SP). The pension benefits do not come from any type of contribution made by the individual. They may be granted universally, as in Bolivia, or targeted as a poverty prevention device. This system can also be funded, partially funded, or not funded. 
For most Latin American and Caribbean countries with PAYG/DB pension systems, the promised benefits are significantly higher than what these countries can afford. On average, in 2015 given current contribution rates, retirement ages, system rules, and demographics, the pensions that could be financed correspond to around 37 percent of the worker's final salary (the variation across countries is substantial). By contrast, the average PAYG/DB system promised pensions equivalent to 67 percent of the worker's final salary. The demographic transition will make that promise even more difficult to fulfill. By 2100 , the pension that can be financed by future contributors will be only 15 percent of the final salary for the same set of parameters (see Box 6.2).

In addition to the high fiscal burden, these promised benefits will likely be paid to a relatively small share of future retirees. This is so because pension coverage is very low in the region. The tension between increasing coverage and maintaining a sustainable system will be a key challenge to fulfilling past promises. Increasing coverage without

\section{BOX 6.1. (continued)}

\section{Funding}

Fully funded. Pension benefits are paid from the assets accumulated through the pension plan. Therefore, pension fund liabilities are fully matched by assets.

Partially funded. Pension benefits are paid both from the accumulated assets and current contributions from workers or general taxes collected by the state. Therefore, liabilities are partially matched by assets.

Unfunded. Pension benefits are paid from contributions or general taxes collected by the state. These systems are typically called pay-as-you-go (PAYG).

Although in theory the combination of systems and funding schemes can vary (see Barr and Diamond, 2006), the region's defined-benefit systems are either unfunded or partially funded. This situation requires a transfer of workers' assets across generations, from those of working age who make contributions to elderly adults who contributed in the past and are now collecting a pension. Fiscal risks for these systems will be greater as demographic pressures mount. Noncontributory pensions (NCP) are an extreme example of a defined-benefit system in which no one contributes directly; instead, they must be funded through general revenues or reserves, or a combination.

Defined-contribution (DC) systems are generally fully funded. Therefore, each generation's pension is financed by its own savings. 


\section{BOX 6.2. FUNDING TO COPE WITH DEMOGRAPHIC SHIFTS}

Demography will transform how much citizens can expect from their pension contributions if systems are to be affordable. This calculation is not easy and depends on the unknown evolution of many variables over long periods of time. However, understanding the balance between what countries promise their elderly and what they ask in the form of contributions and retirement age, is crucial for a proper strategy to cope with demographic shifts.

Demographic forces have a different impact depending on the type of pension system. In systems with PAYG pillars, the expected rate of return for pension financing is the rate of growth of aggregate taxable salaries (Samuelson, 1958; Aaron, 1966). This is the rate at which wages increase times the increase in the size of the contributor's base. Hence, as the contribution's base decreases, so does the average pension that can be paid without relying on other funding sources.

Fully funded capitalization systems will also be affected by demographic changes. As Attanasio et al. (2015) show, in an aging world, interest rates will be lower, decreasing the returns to pension savings. Furthermore, if the retirement age remains constant as longevity increases, those savings will generate lower pensions.

This box estimates the pension based on the last salary (replacement rate) that the average worker should expect under: (i) a sustainable PAYG system; and (ii) a fully funded system, and compares them with what countries are actually promising (Figures B6.1 and B6.2). There are three main messages.

\section{Countries are making unrealistic promises}

For most Latin American and Caribbean countries that have a pay-as-you-go/ defined-benefit (PAYG/DB) pension pillar, promised benefits are significantly higher than what these countries can afford in a sustainable way. This implies that in order to meet those promises, countries will probably have to draw resources from elsewhere outside the pension system and trade-offs will arise between competing development needs.

The mismatch between promises and what can be afforded occurs because benefits are generous with respect to the contribution rate (which is calculated as a percentage of a worker's salary) and retirement age in the country. For example, in Honduras, whose contribution rate is only 3 percent of the salary, retirees are entitled to a pension that could be between 65 percent and 70 percent of the final salary (although with a relatively low pension ceiling). In Jamaica and Haiti, which also have contribution rates of 3 percent, retirees can receive benefits in the range of 30 percent of their final salary. While this is significantly lower, it is still very generous given the level of contributions paid. For PAYG/DB pillars in countries like Belize, Mexico, Costa Rica, Venezuela, and Ecuador with contributions between 6 and 8.7 percent of salary, promised replacement rates are over 60 percent with respect to the final salary. In Mexico, for a contribution rate of 6.3 percent of salary, some 
BOX 6.2. (continued)

\section{Figure B6.1 Promised and Affordable Replacement Rates in PAYG/DB and FF Systems for Retirees in 2010-15 and 2095-2100}

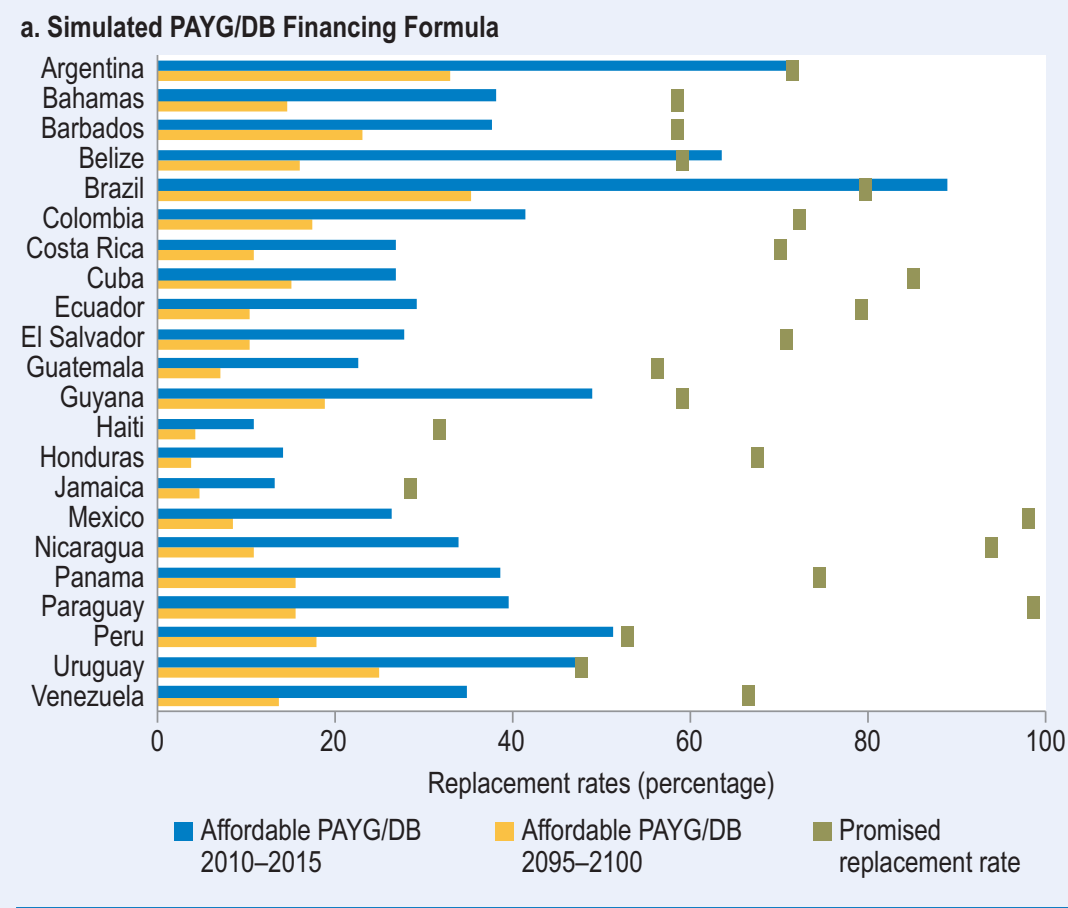

beneficiaries are entitled to a pension close to 100 percent of their final salary. ${ }^{\text {a }}$ Nicaragua and Paraguay, which have somewhat higher contribution rates, have committed to pensions close to the level of the worker's final salary. But, as shown in panel a, this might still be unaffordable with the prevalent contribution rates (11 percent and 13 percent, respectively) and current retirement age (60 years) in those countries.

The non-affordability problem becomes aggravated as the population ages. Simulations show that in all cases, the affordable replacement rates over the 2095-2100 period are significantly below the affordable replacement rates in the present. For promised benefits to be affordable, huge increases in contribution rates would be needed (or retirement ages should be incremented substantially). For instance, in Nicaragua and Paraguay, where the current contribution rate is 11 percent and 13 percent, respectively, and promised benefits are over 90 percent of the final salary at age 60, contributions would need to be around 25 percent in 2010-15 and soar to over 70 percent in 2100, in order for benefits to be paid without generating an actuarial deficit. 
BOX 6.2. (continued)

Figure B6.1 Promised and Affordable Replacement Rates in PAYG/DB and FF Systems for Retirees in 2010-15 and 2095-2100 (continued)

b. Simulated Fully Funded Financing Formula Assuming 3.5 Percent Real Return

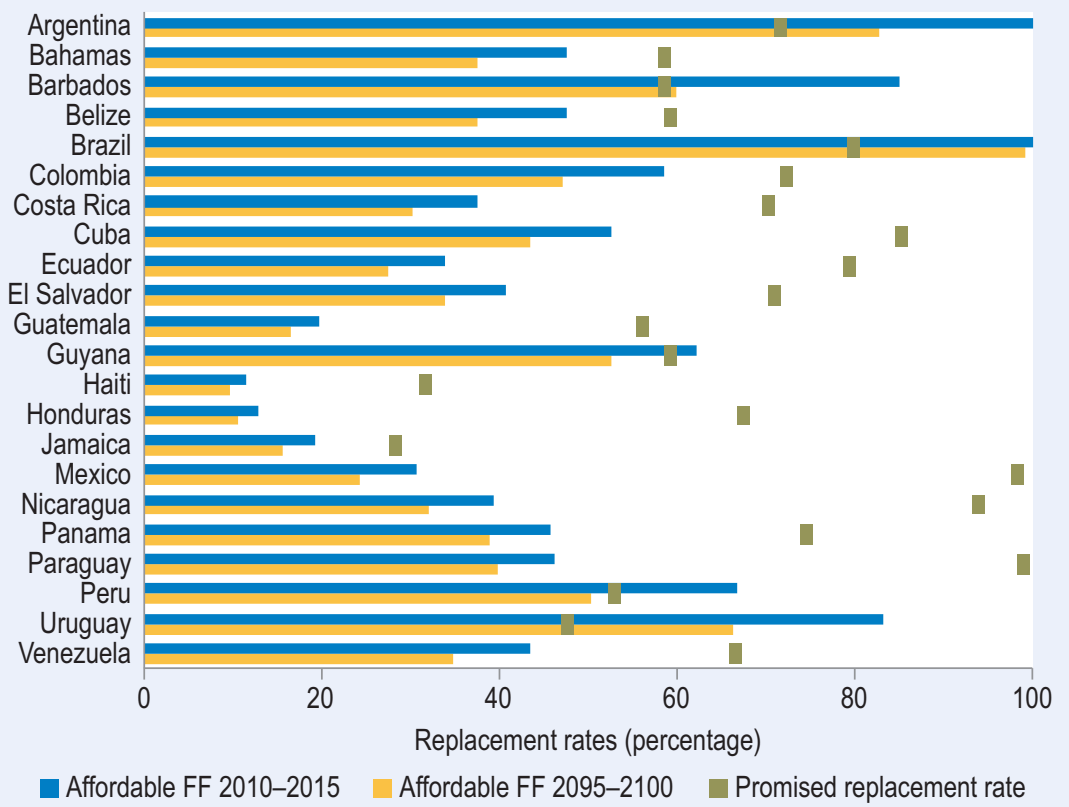

Source: Authors' calculations based on system's design parameters and their own assumptions. Note: $P A Y G=$ pay as you go, DB = defined benefit, FF = fully funded.

\section{Moving to funding might help but pensions will probably remain lower than promised}

Suppose now, that the system was fully funded; i.e., that the same worker accumulated contributions in an individual account and was paid the same promised pension at retirement. Of course, the affordability of the promised pension (assumed to be the same amount as in the preceding example) will now hinge on the returns on the accumulated assets. To assess the level of affordable replacement rates, the exercise assumes a constant real rate of return of 3.5 percent on accumulated assets. Panel b of Figure B6.1 illustrates the affordable replacement rates now and in 2095-2100, taking into account how demographic changes impact affordable benefits under fully funded systems.

Overall, as panel $b$ shows, compared to the unfunded PAYG/DB, the level of affordable benefits is generally higher and the impact of aging is generally smaller for fully funded schemes (assuming a 3.5 percent return). Moving toward funding could help increase savings and also the capacity of 
BOX 6.2. (continued)

countries to finance adequate benefits for future retirees for relatively low interest rates. Nevertheless, pensions might still need to be lower than currently promised benefits in some countries and/or parameters might need to be changed.

These exercises may overestimate the benefits of funding as they may not take into account the indirect impact of declining real returns on savings as the population ages. In simulations by Attanasio et al. (2015), the world's interest rate declines from 4 percent in 2010 to 1.5 percent by 2100 . If this were the case, increasing funding would provide less benefit. On the flip side, if savings are well invested and thus generate higher productivity growth, then the benefits of funding pensions would be higher.

\section{Some countries will benefit more from funding than others.}

In relation to present time affordability, Panel b shows that for some countries with relatively young populations, including Belize and Guatemala, affordable replacement rates under fully funded arrangements are lower than under unfunded PAYG/DB. For other countries-for example, the Bahamas, Ecuador, Haiti, Mexico, Nicaragua, Panama, Paraguay, and Venezuela-funding helps to increase affordability, but by less than 20 percent vis-à-vis the affordability of the unfunded PAYG/DB. Finally, for countries with a more advanced demographic transition, such as Argentina, Brazil, and Uruguay, the benefits of funding in terms of increasing affordability are very large vis-à-vis the PAYG/DB systems. Nevertheless, it is important to consider that funding implies important transition costs, given that rights to retired workers must be preserved.

a This system has been replaced by a fully funded system, and therefore this extremely high level of benefits is transitory.

increasing contributions (for example through noncontributory pensions) might make it difficult to sustain the system in some countries. On the other hand, low coverage directs benefits to relatively high-income people (who tend to be the ones that are covered), resulting in high inequality.

Families face similar challenges. The way families take care of elderly relatives resembles a PAYG/DB system. The young take care of the old with their own resources, not in exchange for previous payments but because of family altruism. This arrangement will also be tested in the future. Smaller families will find it more difficult to take care of a greater number of elderly. 


\section{Saving for the Future}

Saving for the future is a reasonable way to prepare for the demographic change, but it is not without problems. Putting resources aside, investing them, and using them when needed is a good strategy from the individual point of view. Intuitively, the more countries save, the less they will need of current transfers from the working generation. However, what may be optimal from the point of view of the individual may not be optimal in the context of global aging. Indeed, if a large proportion of the population saves during their active years and then sells those assets to the next generation (which will consist of fewer people because of the demographic transition) the prices of those assets will decline, and hence the ability of this up-and-coming group to finance its future will be at risk. One of the key findings in Attanasio et al. (2015) is that future returns on saving (i.e., interest rates) in an aging world will be lower. Indeed, a situation in which there is "too much saving" can lead to an inefficiently high level of capital (Diamond, 1965). However, this is definitely not the case in Latin America and the Caribbean in the present, where more saving is needed to finance productive investment (see Chapter 4). Even if interest rates decline in the future as the population ages, the affordable level of pension might still be higher for countries that built savings buffers (see Box 6.2).

A crucial point to understand is that there is no unique way of saving for the future. Countries that have chosen PAYG/DB pension systems can and should save by reforming the parameters of PAYG/DB systems (i.e., retirement age, contribution rates, and salary replacement rates) that threaten their sustainability. Setting aside resources, either public or private, while demographics still permit, to fund future pensions in preparation for the demographic transition is another way of saving.

Transitioning from PAYG/DB to fully funded defined-contribution systems with individual accounts is yet another way to increase saving. That was the route taken in many countries in the 1990s. However, this is not a magic solution. It must take into account the transition costs of meeting the obligations of past promises. As discussed in Chapter 7, these transition costs have proven to be very large for many countries. ${ }^{6}$ In addition, mandatory contributions to individual accounts may not necessarily increase private saving if they displace saving through non-pension vehicles (Attanasio and Rohwedder, 2003; Attanasio and Brugiavini, 2003). In all, the evidence shows that for countries that 
switched from PAYG/DB to defined-contribution systems, the resources channeled to individual accounts were not fully offset by a decrease in non-pension saving, and thus aggregate saving increased (see Bebczuk [2015a] for a recent survey of the literature and new results). Even so, funding (saving) entails other problems related to risk sharing and pension adequacy that are present in defined-contribution systems. These issues are addressed in more detail in Chapter 7.

\section{More-and Better-Savings to Enhance Growth}

Not only does the region need more savings, but it also needs better savings. Being prepared for the future entails both an increase in savings, which will alleviate the burden on future generations, and an improvement in the efficiency with which those savings are used, which will boost productivity, and therefore the returns to those savings (see Chapter 10). Savings can help a society and individuals prepare for the future in at least two ways. First, savings that are channeled into productive investments with higher returns can help overcome the demographic transition. Of course, this requires well-functioning financial markets to intermediate savings (see Chapter 11). Second, if savings lead to higher aggregate productivity growth, they support whatever strategy a country has chosen to take care of the elderly. For example, if pension design entails benefits based on intergenerational promises (as PAYG/DB systems), higher productivity leading to larger output can help meet those promises, even as the share of dependents increases with population aging. ${ }^{7}$ If, instead, accumulated assets back pensions (as in defined-contribution systems), a smaller cohort of workers with higher wages can support the demand for assets and mitigate a drop in rates of return. Any policy that promotes productivity growth can thus help alleviate the ill effects of an aging society (See Box 6.3).

\section{How Is the Region Preparing for the Future?}

Despite better macroeconomic management and pension reforms in recent decades, the region is ill prepared to confront the challenges of the demographic transition. Participation in formal pension plans is low; thus, so is pension coverage. Other forms of saving are not playing a significant role in providing income security for the elderly. And, given that families are shrinking in size, financing old age in this way will be difficult. 


\section{BOX 6.3. PRODUCTIVITY IN AN AGING WORLD}

Predicting what will happen with the saving rate as societies age is a complex exercise. There are several forces at play. The most direct impact of demographic changes on overall saving rates is through the age structure of the population. Simply put, the working-age population is doing the saving in countries, while elderly people consume. When the balance shifts toward an aging society, aggregate savings decrease; this would be the first order direct impact.

However, as the demographic transition continues, other forces come into play. Smaller families mean fewer dependents to take care of, which frees up resources for saving. Moreover, as life expectancies increase, rational individuals will save more, as they foresee longer retirement periods.

Therefore, individual responses to changes in family size and life span (El Mekkaoui de Freitas and Oliveira Martins, 2014) could totally or partially offset the effect of the change in the age structure of the population (Heller, 1989).

Attanasio et al. (2015) build and simulate a model to understand the quantitative impact of these forces in a context in which demographic trends around the world are not synchronized and capital can flow across regions. Under a benchmark scenario in an open economy, the saving rate of Latin America and the Caribbean should increase in the next two decades. The effect of having more consumers than savers would be offset by an increase in savings associated with smaller families and stronger saving motives for retirement as life expectancy increases. After that, savings in Latin America and the Caribbean would decline gradually as longevity stabilizes and the first order effect takes over.

Models like this one help explain how different forces interact in the demographic transition and affect savings. For instance, in an exercise that isolates the impact of fertility, the model shows that the driving force for the decrease in future savings, under the benchmark scenario, is lower fertility. Indeed, if fertility is assumed to be constant instead of decreasing, then saving rates should be 6 percentage points higher than in the benchmark scenario by 2100 . Essentially, more working-age people would generate more saving.

The model can also help explain how productivity growth can contribute to the saving rate. Total factor productivity (TFP) is what the economy is capable of producing beyond the use of labor and capital. Attanasio et al. (2015)

\section{Pension Systems: Not an Option Today}

Coverage of mandatory contributory pension system is low. Today only 45 percent of workers are contributing to a pension system, many of them irregularly. This share has been roughly constant over the last two decades (Figure 6.5). If the contribution patterns do not change 
BOX 6.3. (continued)

\section{Figure B6.2 Saving Rates for Open Economy}

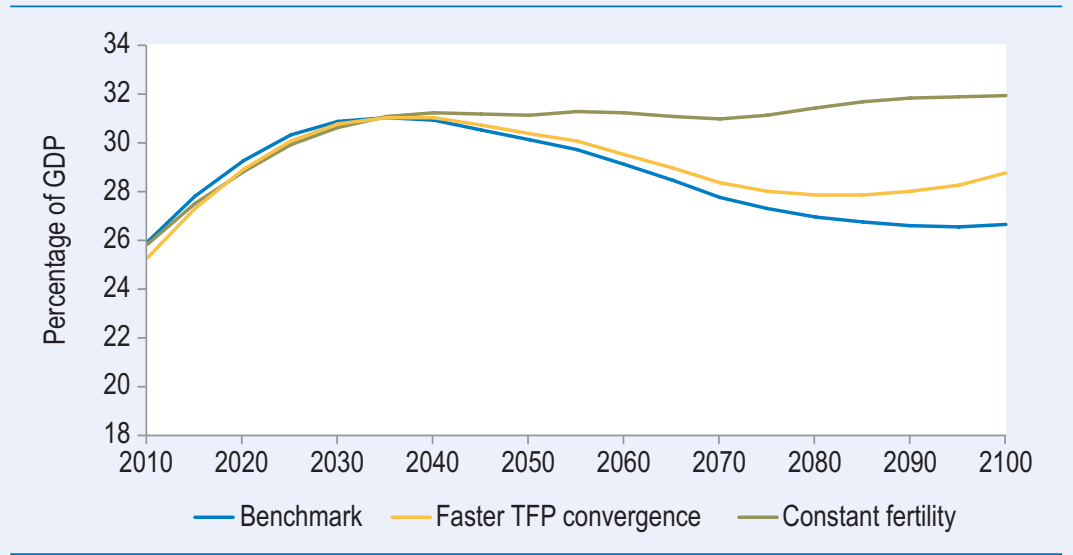

Source: Authors' calculations based on Attanasio et al. (2015).

model the benchmark scenario to assume that Latin America and the Caribbean converges to the productivity of more developed countries by 2150 , with a growth rate of 1.5 percent from then on. This implies that TFP grows by 1.41 percent per year from 2010 to 2150 in Latin America and the Caribbean to achieve the same level and growth rate as high-income countries.

To assess the importance of productivity on savings and future growth, the model explores a scenario of rapid convergence, in which it is assumed that the TFP level and growth in Latin America and the Caribbean will reach the levels of high-income countries by 2100 , instead of 2150 . TFP is assumed to grow 1.51 percent annually from 2010 to 2100 . In this case, an additional 0.1 percent of productivity growth from 2010 to 2100 can moderate the fall in saving rates due to lower fertility by about one-third (2 percentage points). Bearing in mind all the caveats of this stylized exercise, these results illustrate that not only does the amount of saving matter to be able to cover the needs of the future population, but also how countries invest those savings is important.

dramatically, coverage will be very limited for the next few generations as well. Between 60 and 80 million people over 65 will not have contributed for a pension in 2050 (Bosch, Melguizo, and Pagés, 2013).

Coverage is not only low, but highly inequitable as well (Figure 6.6). In virtually every country in the region, the poorest households are not, 
Figure 6.5 Share of Workers Contributing to Pensions, 1993-2013

Population aged 15-64

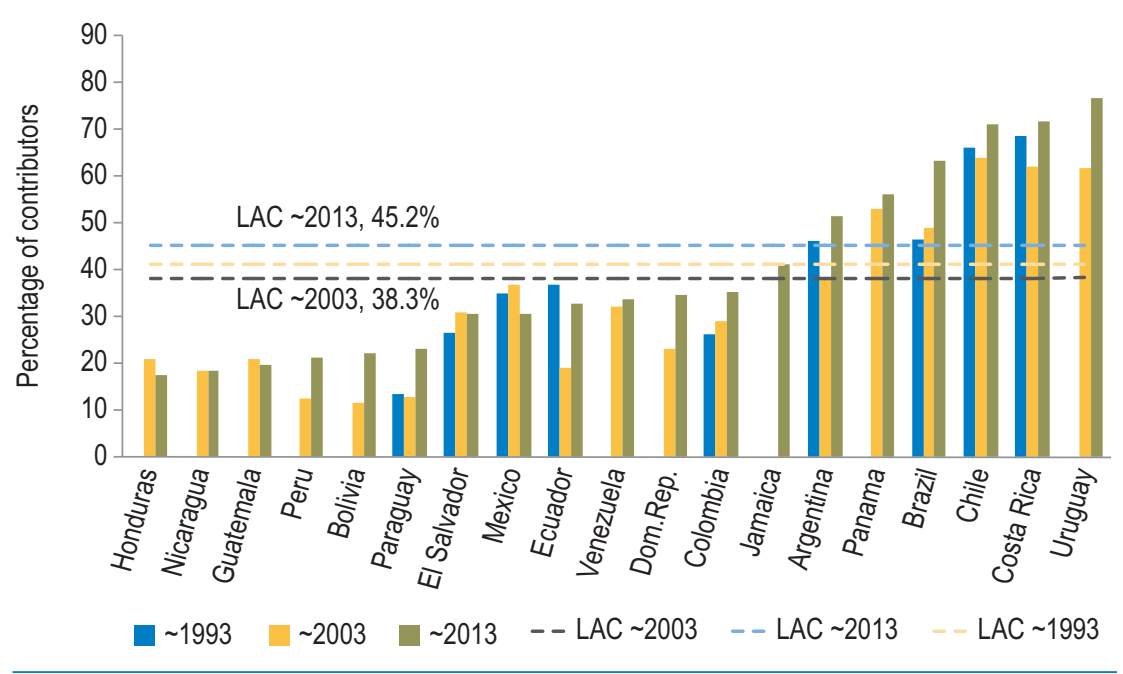

Source: Authors' calculations based on the IDB's Labor Markets and Social Security Indicators System database.

Note: Data circa 2013.

Figure 6.6 Share of Workers Contributing to Pensions, by Daily Income, circa 2013

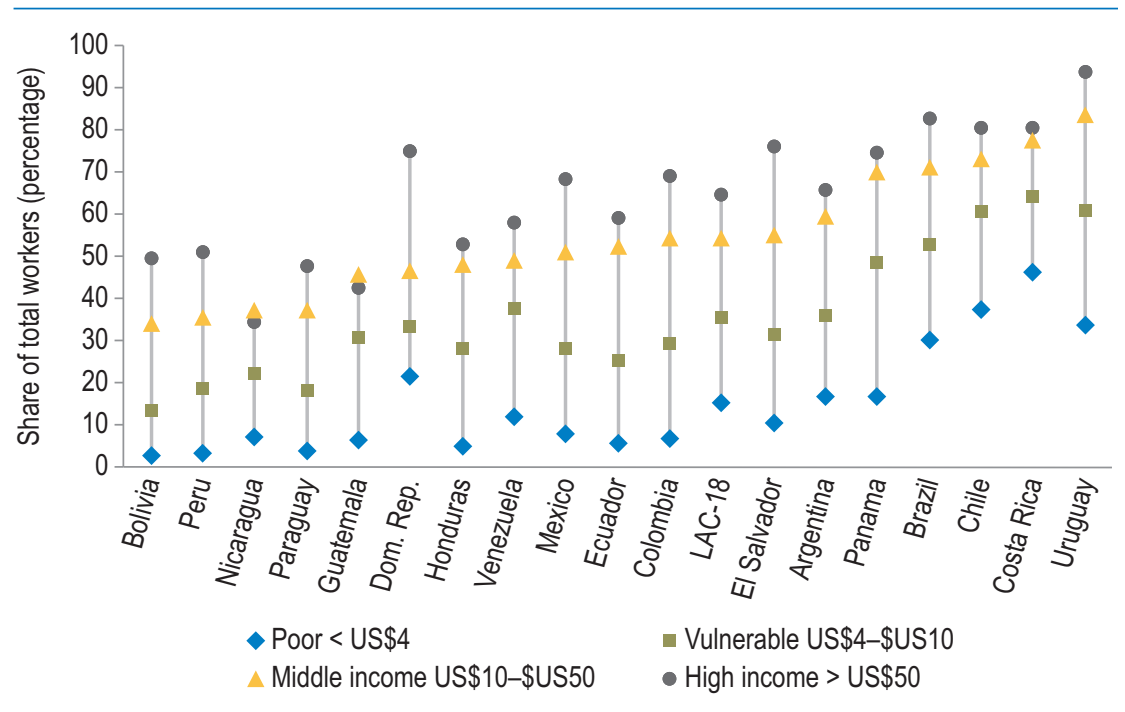

Source: Authors' calculations based on the IDB's Labor Markets and Social Security Indicators System database.

Note: Income classification as of 2005 in purchasing power parity (PPP) terms. 
and will not be, covered by mandatory pension systems. On average, only 15 percent of the workers with incomes below US\$4 a day in purchasing power parity terms (the standard moderate poverty line used in the region) contribute to pensions. Even the new emerging middle class is largely left out of pension coverage (Ferreira et al., 2013). On average, only 53 percent of all middle-income workers (defined as those earning between US\$10 and US\$50 a day in 2005 purchasing power parity terms) currently contribute to pensions.

Furthermore, many of those who contribute at a given moment in time will not become eligible for an adequate pension. Contribution densities (the share of active working life during which workers contribute to a pension system) are very low. In Chile, one of the countries with higher coverage, only 59 percent of men and 30 percent of women aged 25 to 60 have contribution densities over 50 percent (Berstein et al., 2006). In Mexico, El Salvador, and Peru, only between 20 to 30 percent of men and 10 to 20 percent of women contribute during more than 50 percent of their active lives (Bosch, Melguizo, and Pagés, 2013).

On the other hand, the pension rules that still exist in many pension systems remain relatively generous; this will generate a regressive redistribution of resources from low- to high-income households who are the ones that are covered (see Chapter 7). Furthermore, in some countries pension systems could become a source of fiscal deficits (public dissaving) that could threaten their sustainability.

Every country in the region faces the same challenges with varying degrees of intensity according to the country's pension system structure. Regardless of the pension arrangement (i.e., whether it be PAYG/ DB or Defined Contributions), a common trait is low active coverage. This pattern suggests that coverage has little to do with the actual pension system and more to do with the overall functioning of labor markets.

\section{Plan B: Household Savings in Other Assets}

Households could be preparing themselves for the future in a different way. They could be bypassing mandatory pension systems (working informally), but compensating with savings in other assets. However, little household savings is occurring outside the pension system, particularly among lower-income households-precisely those most often on the margin of the pension system. Workers, and their families, who do not contribute to 
Figure 6.7 Share of Workers Who Report Savings in the Previous Year
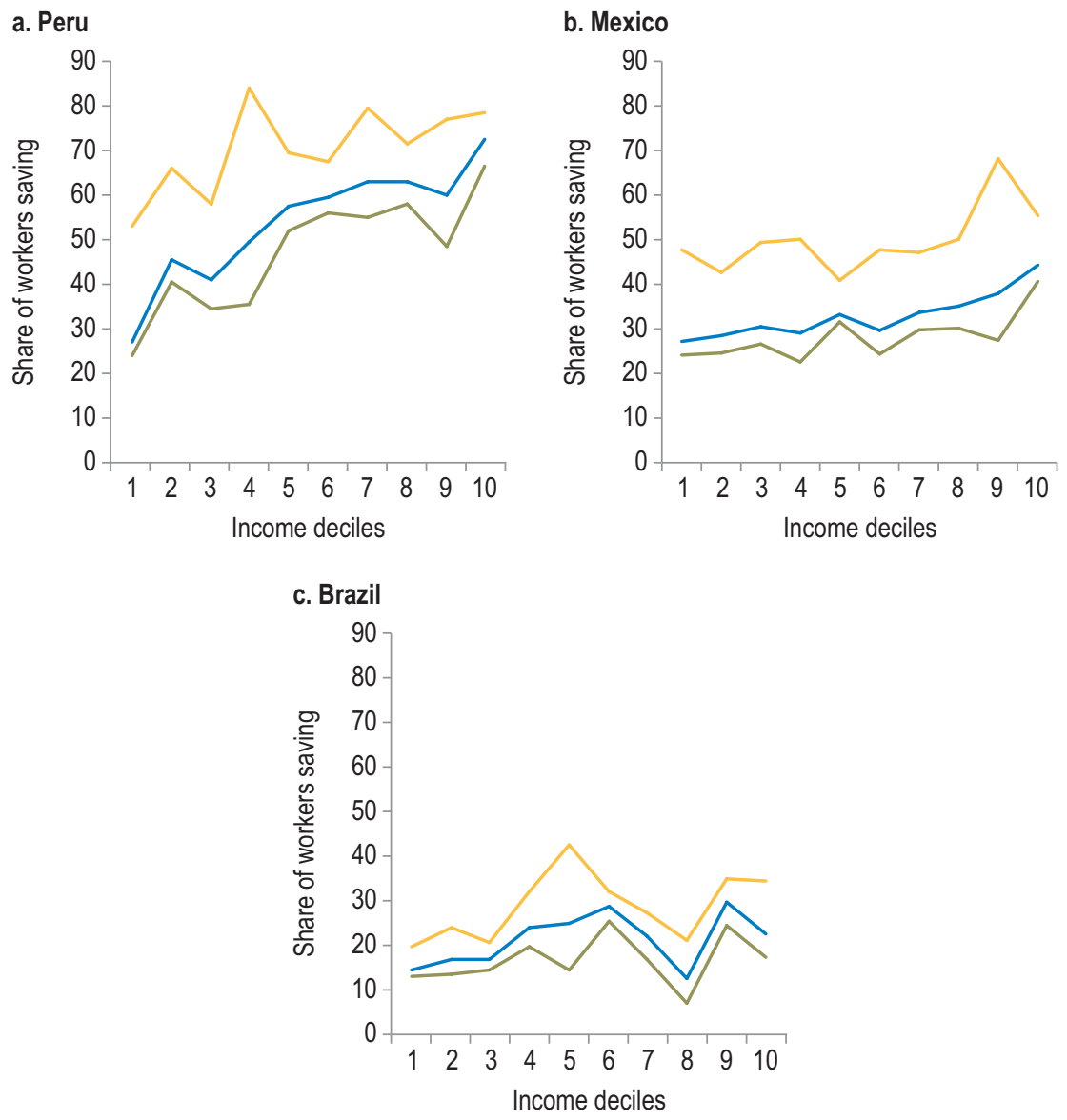

— Total — Contributing to pensions — Not contributing to pensions

Source: Authors' calculations based on the Base of Pyramid (BoP) Survey.

Note: The survey excludes the richest 30 percent of the households in each country. The decile distribution maps the poorest 70 percent of the households.

pensions, do not save more than workers who contribute. On the contrary, surveys in Brazil, Mexico, and Peru show that informal workers (who do not contribute to pensions) save less at every income level (see Figure 6.7). Furthermore, not only do informal workers save less at every income level they largely do so through informal means (see Chapter 3).

These patterns are occurring during a generally favorable time to save in demographic terms. Since the society is still relatively young in Latin America and the Caribbean, savings should be high. However, saving rates do not always respond to movements in demographics. Asia is 
the only major region in the world to substantially increase savings during the demographic dividend (Cavallo, Sánchez, and Valenzuela, 2016). The decline in the dependency ratio can explain 22 percent of the saving increases between 1963 and 2012 in Asia, but only 3 percent in Latin America and the Caribbean during the same period.

Why doesn't Latin America and the Caribbean seem to be taking advantage of good demographics to increase saving? There are multiple reasons. Despite the last decade of growth, the region is still relatively poor and unequal. Many individuals and families cannot cover basic needs. A relatively large segment of the population earns too little to accumulate substantial savings in general, much less for a potential retirement, be it through formal pension contributions or through nonpension instruments. According to social protection surveys in Mexico and Peru (IDB, 2008), approximately 30 percent of those who do not contribute give insufficient income as the main reason (see Figure 6.8). This situation could explain the high correlation between a country's per capita income and the percentage of formal workers (Loayza, Oviedo, and Servén, 2005) as well as the relationship between an individual's income level and the probability that he or she will save for retirement (see Figure 6.6). It could also explain why the demographic dividend has had little effect on saving patterns in the region.

\section{Figure 6.8 Why Don't Workers Contribute to Pensions?}

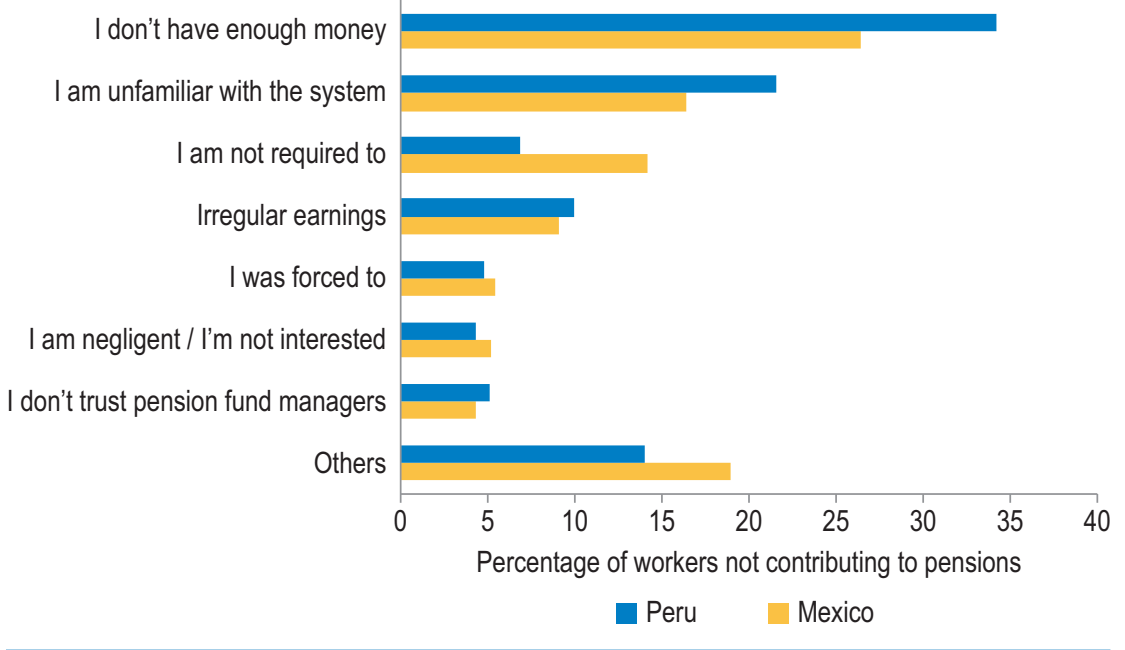

Source: Authors' calculations based on the Social Protection Survey in Mexico City and Metropolitan Lima, Peru (IDB, 2008). 
While for low-income workers saving for retirement may not be feasible, it is less clear why the middle class in Latin America and the Caribbean is not saving enough. Income restriction should be less of an issue. However, all potential savers confront several barriers to generating savings for retirement outside mandatory pension systems. Chapter 9 explores two likely explanations. The first is a general lack of trust in the financial system and low effective returns to financial savings. Second, proactive savings behavior (particularly long-term savings) may be undermined by behavioral biases, including present bias, discount factors, myopia, agency problems within the household, and pure irrationality. ${ }^{8}$ Given these limitations, relying on saving outside a mandatory pension system almost guarantees that resources to finance pensions will be insufficient.

\section{The Last Resort: Taking Care of Grandma}

Many Latin American and Caribbean citizens who do not contribute to mandatory pension systems hope they will be able to support themselves by remaining in the labor market. Labor income is an important source of income in old age, at least between ages 60 and 80 (Figure 6.9). A large majority of informal workers in the region rely on working until a very advanced age (Bosch, Melguizo, and Pagés, 2013). However, labor supply patterns in the region suggest that very few people are willing or able to work past 80 . Only 17 percent of men and 6 percent of women are working by the time they turn 80 . Unless labor support patterns change dramatically, labor income will not be a reliable source of funding for old age.

The other source of support for the elderly outside pension systems is the family. Families have traditionally been the most reliable safety net for the elderly. ${ }^{9}$ In 2013, around 57 percent of adults 65 and older were living with working-age family members (not including spouses). However, families are unlikely to be a reliable source of support as aging continues. The average woman in 1950 in Latin America and the Caribbean had six children. In 2015, the average woman had just enough children to maintain the population level (around 2.1). The implications of this dramatic shift are just emerging. From 2000 to 2013, household surveys reveal that the average size of households shared by adults 65 and older and working-age population decreased by 9 percent (from 4.4 to 4 members), mimicking an overall trend of smaller households 
Figure 6.9 Sources of Income in Old Age

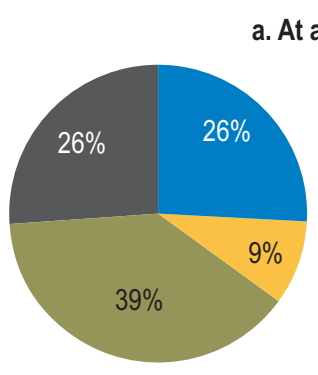

At age 60

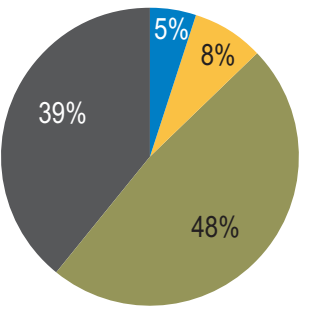

At age 80

b. At age 60 and 80 for males

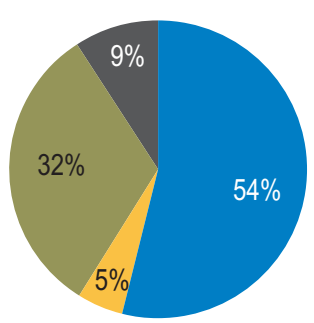

At age 60

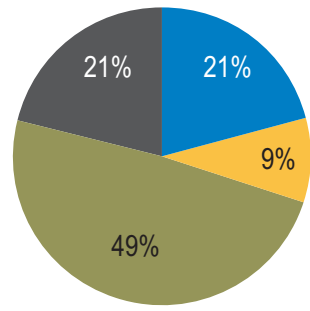

At age 80

- Labor Capital Pension $\square$ Transfers

Source: Authors' elaboration based on Saad (2011).

in the region. In just 13 years, the average household in Latin America and the Caribbean decreased by 12 percent (from 4.9 to 4.3 members). Several demographic, cultural, and economic trends may be behind this decline, but one thing is certain; families are getting smaller. Maintaining the elderly will be more difficult without rapid economic growth. Smaller families will have fewer descendants to take care of elderly parents. Meanwhile, parents have children at a later age. Thus, working-age parents may have to take care of their children, parents, and grandparents. Women, who are traditionally the main caregivers of the elderly, will likely suffer the most from these changes in family structure.

\section{Act Today, for a Better Tomorrow}

Aging is a reality that countries will have to face in the future, but the future is approaching rapidly. Longer lives are certainly good news; however, longer lives will not be better lives if there is no appropriate 
financing. Latin American and Caribbean countries, like all regions around the world, will have to face this challenge.

The dramatic transformation in the age profile in the region and the changes that it will bring are difficult for both citizens and policymakers to grasp. In principle, individuals could predict the changes in demographics and take the appropriate steps to secure their future income by saving more. However, people do not save enough for retirement in the region. Many must contend with immediate needs. Others do not foresee their future needs or think they will be able to work until a very advanced age. Indeed, this is the main reason pension systems around the world have compulsory social arrangements. However, compulsory arrangements by and large have failed to prepare the countries of the region for the demographic change. While policymakers clearly recognize the challenge, the problem seems too far away and beyond the scope of the typical four-year mandate.

What policies can secure the necessary resources for the aging population without compromising other competing needs? Saving more for the future could play a central role, but only if it addresses the fundamental challenges of an aged society. Saving per se will not necessarily secure the funds needed to take care of large numbers of elderly in the future. A large generation followed by a small one implies that savings might have lower returns and higher volatility. Savings not only need to be higher, they must be mobilized in a way that enhances productivity and generates economic growth. This is the only way that countries will be able to afford the ever-increasing costs of an aging society.

Although the window of opportunity is closing on the demographic dividend, Latin America and the Caribbean has significant room to grow in the coming years. Well-designed pension systems that are better prepared to cope with aging will be crucial to meeting this challenge. How to reform these systems to increase coverage in sustainable ways while at the same time dealing with an aging population will be covered in the next chapter.

Increasing savings and funding the pension systems now could boost the economy and prepare for the graying of the region. The current age composition in the region supports these steps. Seizing this opportunity in Latin America and the Caribbean in the decades to come will be vital to secure the region's future. 


\section{Notes}

1 The demographic dividend is defined by the United Nations Population Fund (UNFPA) as "the economic growth potential that can result from shifts in a population's age structure, mainly when the share of the working-age population (15 to 64) is larger than the non-workingage share of the population (14 and younger, and 65 and older)."

2 For a global perspective of the aging phenomenon, see Lee and Mason (2011b).

3 Between 1993 and 2013, around 60 percent of the GDP per capita growth in the region was due to increases in employment because of population growth, while the other 40 percent was due to increases in output per worker (Alaimo et al., 2015).

4 FADL include activities such as walking, eating, dressing, and toileting. IADL include activities such as shopping, answering the phone, preparing food, housekeeping, and the ability to handle finances.

5 This analogy and the text in section draws on Barr (2002) and Barr and Diamond (2009).

6 Something that is not observable is the path that countries that switched from PAYG/DB to fully funded private accounts might have followed if they continued unreformed. In this sense, systems with escalating costs and potential pressures to increase benefits or relax access to benefits could have ended up with large deficits and consequently important dissaving.

7 However, it is important to understand how those "pension" promises are made (see Chapter 7).

8 For evidence of insufficient savings for retirement in the United Kingdom, see Banks, Blundell, and Tanner (1998).

9 For a discussion of how transfers across generations may act as a substitute for savings in the absence of well-functioning private annuity markets, see Kotlikoff and Spivak (1981) and Kotlikoff (1988). 


\section{()요 $\Theta \Theta$}

This chapter is distributed under the terms of the Creative Commons Attribution-NonCommercial-NoDerivatives 3.0 IGO license (http://creative commons.org/licenses/by-nc-nd/3.0/igo/) and may be reproduced with attribution to the Inter-American Development Bank (IDB) and for any non-commercial purpose. No derivative work is allowed.

Any dispute related to the use of the works of the IDB that cannot be settled amicably shall be submitted to arbitration pursuant to the UNCITRAL rules. The use of the IDB's name for any purpose other than for attribution, and the use of IDB's logo shall be subject to a separate written license agreement between the IDB and the user and is not authorized as part of this CC-IGO license. Note that the link provided above includes additional terms and conditions of the license.

The images or other third party material in this chapter are included in the work's Creative Commons license, unless indicated otherwise in the credit line; if such material is not included in the work's Creative Commons license and the respective action is not permitted by statutory regulation, users will need to obtain permission from the license holder to duplicate, adapt or reproduce the material. 